\title{
Intra-European Union Imbalances and Cyclical Position: Does Monetary Policy Matter?
}

Jean-Pierre Allegret

EconomiX, UMR 7235 CNRS and University Paris Ouest Nanterre La Défense, France. Email: jallegret@u-paris10.fr

Audrey Sallenave

LEAD, University of Toulon, France and EconomiX, UMR 7235 CNRS and University Paris Ouest Nanterre La Défense. Email: audrey@sallenave.fr

\section{Introduction}

The aim of this contribution is to investigate the determinants of the cyclical position in some Baltics and South-Eastern European countries as well as peripheral European countries over the period 2000-2013. Specifically, we consider a sample of eight economies: Croatia, Estonia, Latvia, Lithuania, Poland and Romania for the sub-sample of Baltics and South-Eastern European economies; and Greece, Ireland, Portugal, and Spain for the sub-sample covering EMU peripheral countries.

Baltics and South-Eastern European economies included in this study have two main similar features. On the one hand, they have followed a pattern of domestic and external financial liberalization related to their accession process to the European Union. On the other hand, they adopted fixed exchange rate regimes, except Poland and Romania. For their part, two features are especially relevant for our EMU peripheral countries: first, they abandon their autonomy concerning the monetary policy, and, second, the adoption of the Euro leads to the fact that the exchange rate cannot be used as an adjustment mechanism to face negative shocks.

This contribution is related to two strands of literature. The first refers to the literature stressing the ineffectiveness of the one-size-fits-all monetary policy in a monetary union characterized by significant macroeconomic and structural divergences (Pisani-Ferry, 2013; Lothian, 2014). More specifically, using a standard Taylor rule, Nechio (2011) shows that the effective European central bank's (ECB) policy rate has been consistently below the interest rate resulting from the application of Taylor rule in the periphery (Greece, Ireland, Portugal, and Spain) over the period 2001-2009. Analyzing the monetary policy of the ECB from 2002 to 2015, Micossi (2015) stresses that the policy stance has responded more to business cycles fluctuation in core countries than that of the peripheral economies. Such expansionary bias has contributed to the built-up of financial imbalances inside the Eurozone (Brzoza-Brzezina et al., 2013). In a similar way, cheap monetary conditions -coupled with the process of financial integration- have been identified as a factor explaining the increase in current account imbalances in the 
Eurozone (Chen et al., 2013; Tressel et al., 2014). Interestingly, Darvas (2015) notices that these imbalances tend to be excessive relative to imbalances fitted by standard medium-term determinants of current account balances. The increase in intra-Eurozone imbalances, and their persistence, highlights the absence of automatic adjustment mechanisms (Dellas and Tavlas, 2013).

The second strand of literature refers to the influence of monetary policy conducted in advanced economies on emerging countries. Hofman and Bogdanova (2012) suggest that what they name "Great deviation" -i.e. the fact that policy rates remained consistently below the levels implied by the Taylor rule in the 2000s'- in emerging economies is in part explained by the influence of U.S. interest rates on their estimated policy rules. Considering the case of Central and Eastern European countries (CEEC), Kadow et al. (2013) find that CEEC money market rates and euro rates are cointegrated. ${ }^{1}$ Allegret and Sallenave (2015a) show that money market interest rates in Central, Eastern and South-Eastern Europe are significantly influenced by the Eurozone money market rate. ${ }^{2}$ They find also that this influence is especially sizable in countries with pegged exchange rate regimes. Wierzbowska (2015) investigates the transmission of Eurozone shocks to CEEC from $1997 .{ }^{3}$ Her results suggest that Eurozone monetary policy shocks tend to exhibit stronger influence on macroeconomic variable than domestic monetary policy.

The global financial crisis suggests that countries with more leveraged domestic financial system and more rapid growth in credit to the private sector exhibited more output losses than other economies (Berkmen et al., 2012). Considering this important finding, our main objective is to investigate to what extent monetary policy had been effective during the period preceding the financial crisis in our two sub-samples. In other words, we try to respond to the following question: are output losses lower in countries belonging to the Euro zone relative to Baltics and South-Eastern European economies?

The rest of this contribution is structured as follows. Section 2 provides an overview of the macroeconomic and financial imbalances within the euro area and in some Central, Eastern and South-Eastern Europe (CESE). We stress a double dualism inside the European Union between core countries on the one side, and peripheral and CESE economies in the other side. Section 3 investigates the effectiveness of monetary policy to manage such imbalances. We proceed in two steps. In the first, we simulate Taylor rules for each studied countries in order to see to what extent the effective monetary policy has suffered from an expansionary bias. Such analysis is conducted for both peripheral and CESE countries. In a

\footnotetext{
${ }^{1}$ Their sample includes Bulgaria, Czech Republic, Estonia, Hungary, Latvia, Lithuania, Poland, and Romania over the period from January 2000 to August 2009.

${ }^{2}$ The dataset covers a time span period of 13 years, from 2001Q1 to 2013Q4, and encompasses the following countries: Bulgaria, Croatia, Estonia, Hungary, Latvia, Lithuania, Poland, Romania, and Serbia.

${ }^{3}$ For a sample encompassing Bulgaria, Czech Republic, Hungary, Latvia, Lithuania, and Poland.
} 
second step, we compare the simulated Taylor rules for our selected CESE countries with the Eurozone Taylor rule. The main purpose of this counterfactual exercise is to see how participation in the euro area could improve the performance of monetary policy in these countries. A last section concludes.

\section{The built-up of macroeconomic imbalances: Lessons from the European Commission's MIP procedure}

This section analyzes the accumulation of macroeconomic imbalances by devoting a specific attention to the period preceding the onset of the global financial crisis. Three country groups are distinguished:

- the core countries of the Eurozone including Finland, France, and Germany;

- the peripheral countries of the Eurozone, i.e. Greece, Ireland, Portugal, and Spain;

- the CESE economies members of the European union, i.e. Croatia, Estonia, Latvia, Lithuania, Poland and Romania.

In order to assess these macroeconomic imbalances, we use the Macroeconomic Imbalance Procedure (MIP) Scoreboard launched by the European Commission (EC) in 2012 as part of the annual Alert Mechanism Report. Indeed, the MIP allows us to measure the extent of imbalances by referring to the alert thresholds determined by the EC.

\subsection{Macroeconomic imbalances}

In this subsection, we study the evolution of macroeconomic imbalances in the three country groups. Four indicators are considered.

Figure 1 exhibits the fiscal balance in percentage of GDP over the period 20002014. The MIP does not specify an alert threshold for this indicator. So, we choose to draw the 3 percent limit -the horizontal line- defined in the Treaty on Stability, Coordination and Governance (2013) to appreciate the path of fiscal balances in the studies countries. On average, we see that until the onset of the Global financial crisis, the trajectories of fiscal balances do not significantly diverge across country groups. In other words, the main culprit of the increase in fiscal balances dispersion has been the fiscal consequences of the recession in the aftermath of the Lehman Brothers collapse in September 2008. This general overview masks some heterogeneities between countries, Poland showing a higher deficit than other economies before the crisis while Finland experienced a sizeable surplus.

Figure 2 portrays the evolution of current account balances in percentage of GDP from 2000 to 2014. The MIP considers two thresholds estimated as the 3 year backward moving average: $+6 \%$ (excessive surplus) and $-4 \%$ (excessive deficit). The figure shows a clear divergence in the Eurozone between peripheral and core economies, what Cesaroni and De Santis (2015) name the "core-periphery dualism". On the other hand, a similar divergence is observed for CESE countries relative to core Eurozone. Except Ireland, all peripheral and CESE economies 
experienced excessive deficits before 2007. Such threshold has never been reached in core countries. Interestingly, the dynamics of current account balances in the period preceding the Global financial crisis is typical of the accumulation of macroeconomic imbalances in EU. Part of this process is based on structural factors such as investment opportunities due to catch up effects in CESE economies and to future convergence in the periphery. But, as stressed by Darvas (2015), these structural determinants do not account for all of the changes in current account balances. More specifically, as we will see below by considering the conduct of monetary policy, these external unbalances result from weak demand management in both peripheral and CESE countries. For instance, fiscal policies did not mitigate the demand expansions in a context where interest rates were very low. ${ }^{4}$ In addition, the persistence of these current account imbalances has been supported by process of financial integration in the EU allowing cheap financial condition for countries with huge deficit. ${ }^{5}$

Figures 3 and 4 address the evolution of competitiveness in the three country groups. Thus, Figure 3 exhibits labor cost through the 3 year change in the nominal unit labor cost index. The EC distinguishes two alert thresholds: $+9 \%$ for Eurozone countries and $+12 \%$ for non-Eurozone countries. Such distinction is relevant for CESE economies. Except core economies, both all CESE countries but Poland and, to a lesser extent, Croatia, and peripheral Eurozone economies but Portugal show 3 year change above alert thresholds suggesting a degradation in their competitiveness, particularly from 2004 to 2008 corresponding to the boom period. The rising trend in labor costs has been particularly dramatic in Baltics and Romania. Such rising trend is explained by the intensity of the economic boom as suggested by the sizeable increase in their positive output gap just before the onset of the Global financial crisis (Allegret and Sallenave, 2015a).

Figure 4 shows the evolution of the real effective exchange rates from 1998 to 2015. As expected, the real effective exchange rates in CESE countries and in peripheral Eurozone followed an increasing trend in the period preceding the onset of the Global financial crisis. At the opposite, core countries exhibit a relatively stable trend. Clearly, these data confirm that competitiveness losses explain the worsening of the current account deficits in the two first country groups. In addition, if we consider the alert thresholds specified by the MIP -3 years percentage change of the real effective exchange rates based on HICP/CPI deflators, with thresholds of $-/+5 \%$ for Eurozone countries and $-/+11 \%$ for nonEurozone countries- we see that CESE and peripheral economies tend to exhibit real appreciation changes above the thresholds after 2000.

\footnotetext{
${ }^{4}$ For Latvia, see Blanchard et al. (2013) and Suarez (2010) for Spain.

5 Allegret and Sallenave (2015a) stress the increasing vulnerability in many CESE countries due to their dependence vis-à-vis banking flows to finance their current account deficit.
} 
Overall, Figures 1 to 4 confirm not only that macroeconomic imbalances had increased during the 2000s, but they reveal also their persistence suggesting the lack of automatic adjustment mechanisms in the EU.

\subsection{Monetary imbalances}

Monetary imbalances are important insofar as they exert an influence on the real interest rates and, in turn, on the dynamics of private credit and debt. In addition, they represent an interesting illustration of the lack of automatic adjustment in the Eurozone and, beyond, across countries from EU. From this perspective, Figure 5 exhibits the annual rate of change of the money and quasi-money aggregates in the studied countries. As for previous indicators, discrepancies between core economies on the one side, and CESE-peripheral countries on the other hand, are important, particularly during the sub-period preceding the occurrence of the Global financial crisis (i.e. from 2004). The striking feature of Figure 5 is the persistence over time of a stronger monetary growth in CESEperipheral groups. Interestingly, if we compare this figure with that of the current account balances (Figure 2), it is clear that countries with external deficits are also those with faster monetary growth. In other words, while external adjustments should lead to slower (higher) monetary growth in deficit (surplus) countries, the experience of EU shows otherwise. The "euro standard" (Dellas and Tavlas, 2013) lacks the automatic adjustment mechanisms present on the gold standard. Such mechanisms are important to avoid the unstable accumulation of imbalances in countries where their degree of financial integration is almost perfect. A closer inspection of Figure 5 shows that, in the CESE group, monetary growth has been especially sizable in Baltics and Romania. Among peripheral Eurozone group, we observe a weaker increase in monetary growth in Portugal confirming the findings by Reis (2013) according to which Portuguese crash does not rest on major monetary and financial disequilibria.

Figure 6 is related to the inflation rate. A monetary interpretation of inflation leads us to stress that this Figure is largely the counterparty of Figure 5. As a result, inflation is consistently higher in CESE and peripheral Eurozone than in the core. Inflation pressures are particularly high in Baltics suggesting that even fixed exchange rate regime has not been able to discipline authorities in the period preceding the Global financial crisis (Allegret and Sallenave, 2015b).

The main lesson drawn from Figure 7 is that long-term real interest rates were lower in CESE-peripheral countries with respect to those of the core Eurozone. Above all, we remark that the real interest rate gap was particularly high in the period characterized by the economic boom from 2004 to 2007 . This symmetry is important insofar as it suggests that excessive monetary creation has been an important permissive condition for the emergence of leading boom then leading to crash. 


\subsection{Financial imbalances}

It is now widely recognized that financial variables interact significantly with economic cycles. On the one hand, as stressed among others by Borio (2012), the behavior of the financial systems is procyclical. Thus, credit to the private sector dramatically increase in periods of expansion -accentuating such expansion- while credit decreases in periods of recessions and remains tight during the preliminary phases of the recovery. The main implication of this procyclicality is that financial variables exert a destabilizing influence on business cycles. On the other hand, empirical studies suggest that recessions associated with financial crises tend to be more severe and more persistent that other recessions (IMF, 2009). In a similar way, recoveries are slower in the aftermath of financial crises.

In this sub-section we follow Borio (2012) by describing financial cycles in terms of credit and property prices. Indeed, not only these two variables co-vary -as credit is decisive to allow the boom in construction and the rapid rise in property pricesbut their peaks are closely associated with the occurrence of financial crises.

Figure 8 shows the credit flow to the private credit in percentage of GDP. It specifies also the EC's alert threshold of $14 \%$.

This figure has two striking features. First, considering only the Eurozone, the period 2000-2014 is marked by a clear divergence between peripheral and core economies. Specifically, in the period preceding the onset of global financial crisis, we observe a dramatic increase in private credit -particularly important in Ireland and Spain- in the formers while credit remains stable, and below the threshold, in core countries. The global financial crisis and the sovereign debt crisis exhibits a different divergence in which credit collapsed in Peripheral countries, once again especially sizeable in Ireland and Spain. In fact, credit dynamism between Peripheral and Core countries is in part explained by the increase in financial integration in the period preceding the crisis and the financial fragmentation in the aftermath of the crisis (Merler, 2015). Second, CESE economies have also experienced a "double" divergence in the dynamics of private credit: among themselves on the one side; vis-à-vis the core countries on the other hand. A closer inspection of Figure 8 shows that all CESE countries but Poland have stronger credit expansion than core economies. The gap is particularly important during the boom from 2004 to 2008. The credit boom has been very high in Baltics and, to a lesser extent, Romania.

Figure 9, related to annual changes in house real prices, shows that, as expected, in countries where credit expansion has been particularly large, house real prices rose sharply. In other words, countries located above the threshold level concerning credit expansion also show excessive variations -in relation to the critical threshold (6\%)- in house prices. As for the Peripheral Eurozone, financial integration plays a significant role in real estates boom as credit expansion in CESE had been funded from abroad. In addition, Mitra (2011) shows that countries 
suffered from largest swing in GDP growth are those with the highest concentration of capital inflows invested into real estates, as in Baltics.

Leverage and delevaraging -i.e. the debt dynamics- have an influence both on the length and depth of the expansion, the crisis, and the strength of the recovery (Buttiglione et al., 2014). From this perspective, the presence of heterogeneity across countries can explain divergences in their output gap over the business cycle. Figure 10 portrays this debt dynamics by focusing on private sector debt in percentage of GDP. The MIP specifies an alert threshold of $133 \%$. The main lesson drawn from this figure is the dramatic increase in private debt in Peripheral Eurozone countries. Except Greece -despite an increase by nearly four of the debt between 1995 and 2014- all countries show a growth in excess private debt to the alert threshold. The rise is particularly impressive from 2004 to 2009. However, this excess debt in the periphery should not mask the very rapid increase in the leverage in CESE economies in the period preceding the Global financial crisis. Broadly speaking, the magnitude of the rise in private debt ranges from $174 \%$ (Croatia) to $223 \%$ (Romania). As with previous indicators in this contribution, the dynamics of private debt leads us to an important conclusion: during the period 2001-2009, we see a strong divergence between core countries of the euro zone and others. In other words, the years before the global financial crisis and the sovereign debt crisis are clearly marked by divergences in the trajectories followed by many countries of the EU.

Figure 11 exhibits the evolution of output gaps in the studied countries from 2000 to 2015. It is important to consider this variable insofar as it allows us to summarize the main insights resulting from our imbalances indicators. Specifically, the Figure shows that discrepancies in output gaps had followed the increase in imbalances in the EU. Indeed, changes in output gaps tend to diverge significantly from 2005 to 2012. A closer inspection suggests that fluctuations in output gaps had been particularly sizeable in CESE economies, confirming the strong relationships between this variable and changes in imbalances in this group of countries.

\section{The ineffectiveness of the one-size-fits-all monetary policy: A Taylor rule approach}

After introducing methodology and data, we analyzed the main results of our estimates.

\subsection{Methodology and data}

We consider a sample including Baltics and South-Eastern European countries as well as peripheral European countries over the period 2000-2013. More specifically, our dataset encompasses the following countries: Croatia, Estonia, Latvia, Lithuania, Poland and Romania for the sub-sample of Baltics and SouthEastern European economies; and Greece, Ireland, Portugal, and Spain for the 
sub-sample covering EMU peripheral countries. Due to the very high level of inflation rate for Romania in the beginning of the period, we start the time span of our estimation to $2005 \mathrm{Q} 1$ for this country.

We follow the seminal paper by Taylor (1993) insofar as it provides guidelines to assess the conduct of monetary policy. So, we link the nominal domestic interest rate to the inflation rate and the output gap. As Nechio (2011), we apply a coefficient to 1.5 for the inflation rate and 1 for the output gap. The constant term equal to 1 . However, contrary to Nechio (2011), we do not consider unemployment gap $^{6}$ in our simulated Taylor rule but a measure of output gap.

We then simulate domestic standard Taylor rules for each countries that we compare to the Taylor rule identified for the Eurozone. In the case where domestic Taylor rule is upper to the Eurozone one, it means that the concerned countries should have pursued more restrictive monetary policy. Conversely, for domestic Taylor lower to the Eurozone one, domestic countries should have pursued a loosened monetary policy.

The simulated Taylor rule is given by:

$$
\text { Taylor rate }=1+1.5 * \text { inflation rate }+1 * \text { output gap }
$$

The variable inflation rate is the annual rate of change of consumer price index ${ }^{7}$. The measure of output gap is calculated as the cyclical component of the gross domestic product (GDP) expressed in constant term ${ }^{8}$.

Seasonality in GDP series are present for Croatia, Estonia, Greece, Latvia, Lithuania, Romania, and Spain. Indeed, for each of them we observe systematic movements within a year at given time points each year. As a result, we remove seasonality.

Seasonal adjustment involves to filter out this systematic variation by decomposing GDP series into unobserved seasonal and non-seasonal components. More specifically, we attempt to correct time series of the so-called seasonal upward and downward patterns. The idea is then to adjust for these patterns so as to compare more effectively data over time.

We employ the X-12-ARIMA procedure ${ }^{9}$ developed from a moving-average approach based on the definition of seasonality as systematic variations within a given year. The ARIMA part is useful for the identification of extreme values and for level shift that could distort the seasonal adjustment. The X-12-ARIMA procedure can be implemented following two steps. First, we proceed to a linear

\footnotetext{
${ }_{6}^{6}$ Due do data avaibility to the appropriate frequency.

${ }^{7}$ And is extracted from IFS

8 The GDP sources are also taken from IFS.

9 The X-12-ARIMA procedure has been developed by the Census Bureau and Statistics Canada and the Deutsche Bank.
} 
regression ${ }^{10}$ and we model by an ARIMA of the estimated residuals of the linear regression. The preadjusted time series of ARIMA models and forecast are then provided to calculate symmetric seasonal filter. Finally, the seasonal component is calculated as a moving average and the final adjustment is performed. 11

The measure of output gap is estimated by using statistical filter. More specifically, to remove trend movements in the GDP, we employ the Hodrick-Prescott ${ }^{12}$ filter (1980, 1997) that has become a standard method and the most popular filter. The optimality criteria of the HP filter comes from that the second differences of the trend follow a white noise process, meaning that the trend is $\mathrm{I}(2)^{13}$, and that the cyclical components is also a white noise.

Properties of the HP filter in the time and frequency domain are link to the smoothing parameter $\lambda$. The value of $\lambda$ is central as it governs the smoothness of the estimated trend and the shape of the estimated cycle. For our quarterly observed series of real GDP, we consider the smoothing parameter $\lambda=1600$. Hodrick-Prescott filter $(1980,1997)$ motivate this value by the assumption that the ratio of the variance of the cyclical component to the variance of the second differences of the trend ${ }^{14}$ of US GDP is about 1600 . Many other filters are available such as the estimation of an unobserved component models (Harvey, 1989), the Beveridge-Nelson (1981) decomposition or the "canonical" decomposition of Box et al. (1978). Due to the aspect of "data consuming" of these procedures, we prefer to use in this communication the HP filter.

\subsection{Results}

We test two main assumptions. On the one hand, we assess to what extent both CESE and Peripheral countries suffer from the "Great deviation". On the other hand, we investigate if the belonging to the Eurozone can improve the effectiveness of monetary policy for CESE economies.

\subsubsection{The "Great deviation" hypothesis}

In a first investigation, we compare the Taylor rule specific to each country with their respective money market rate. Following Hofman and Bogdanova (2012), our main purpose is to assess to what extent monetary policy has exhibited an expansionary or a restrictive bias. Figure 12 presents the results for the CESE economies. In the period preceding the Global financial crisis, monetary policy is characterized by an expansionary bias in all countries except Poland. It is

\footnotetext{
${ }_{10}$ We regress the observed time series in question on outliers, day-of the-week effect and the residuals form this regression.

11 See Pedersen and Faeste (2006) for more details on the X-12-ARIMA procedure.

12 Hereafter HP.

${ }^{13}$ Integrated of order 2. This means that we have to differentiate two times the trend to obtain a stationary process.

${ }^{14}$ The inverse signal-to-noise ratio.
} 
important to stress that this finding closely fits the time profile of the growing imbalances in the previous section.

In countries with fixed exchange rates -i.e. Baltics and Croatia- the discrepancy between the two interest rates is large. Such finding is in line with the literature stressing that this regime induces more constraints for the conduct of monetary policy. This latter has been more loosened in these countries as suggested by the size of interest rates gaps in countries with fixed regimes and those this floating ones (Poland and Romania) respectively. Fixed exchange regimes constraint the ability of the central bank to raise its policy rates insofar as raising domestic rates may attract more capital flows and, in turn, induce a pressure on the exchange rate. In accordance with the impossible trinity, authorities cannot attain at the same time (i) a fixed exchange rate, (ii) an independent monetary policy, and (iii) free capital movements. The main point is that, within the context of European integration, many Emerging Europe countries have to ensure open financial account in order to respect rules defined in Copenhagen (the so-called "Copenhagen criteria") to be eligible to join the EU. Countries with fixed exchange rate regimes face a conflict between the external constraint -the fixed exchange rate cannot appreciate- and internal constraints such as the control of domestic credit. On the other hand, these countries are reluctant to let their currency appreciate to curb capital inflows (Allegret and Sallenave, 2015b). Interestingly, Poland had adopted a consistent countercyclical monetary policy characterized by a restrictive bias during the boom and an expansionary bias during the collapse.

For the Peripheral Eurozone countries, Figure 13 reports country-specific Taylor rules, the ECB's policy rate, and the Eurozone's interest rate recommended by the Taylor rule. This figure allows us to investigate the effectiveness of the one-sizefits-all monetary policy. Three main lessons can be drawn from this figure. First, for all countries, the ECB's monetary policy has been consistently below the domestic interest rates resulting from the specific Taylor rule. In other words, considering both the output gap and the inflation gap specific to each Peripheral economy, the monetary policy conducted by the ECB has been excessively expansionist. The magnitude of the discrepancy has been particularly sizeable in Ireland, Greece, and Spain from 2005 to 2009.

A second important lesson is the fact that in the aftermath of the Global financial crisis (over the period from 2008-4 to 2010-1), except Greece, the ECB's rate has been too high relative to the domestic interest rate derived from the Taylor rule. Greece has been mainly hit by the sovereign debt crisis from 2010 leading to a major recession. Such shock corresponds to the period where the ECB's monetary policy has been too restrictive for Greece -over the period 2011-4 - 2014-3.

A third lesson results from the comparison between country-specific Taylor rule and the Eurozone's Taylor rule. It offers an additional opportunity to assess the deficiencies of the one-size-fits-all policy in the Eurozone. For all Peripheral Eurozone countries, we see that the ECB's Taylor rule remains too expansionary 
to face the growing imbalances in the period preceding the crisis. In other words, even the application of the Taylor rule in the Eurozone would lead to an expansionary bias in Peripheral countries. In a similar way, in the aftermath of the Global financial crisis and the sovereign debt crisis, the ECB's policy would be too restrictive, in particular for Greece.

3.2.2. Is monetary policy would have been more effective with membership of the Eurozone: A counterfactual analysis

In this sub-section, we provide some answers to a fundamental question: whether membership in the Eurozone could have improved the effectiveness of monetary policy in CESE countries in the period 2000-2008.

In order to conduct a coherent analysis throughout this contribution, we proceed as follows. We compare the specific-country Taylor rule to Eurozone's Taylor rule. The purpose is to determine to what extent the adoption of the ECB's monetary policy would reduce the expansionary bias observed in CESE countries. As our Taylor rules do not take into account the exchange rate, it is important to check the robustness of this choice. To this end, Figure 14 estimates two Taylor rules: one without the exchange rate (named Taylor rule) and the other with the bilateral exchange rate against the euro (named Extended Taylor rule).

The estimates are based on the following methodology.

We estimate the Taylor rule and the extended Taylor rule by using quantile regression for each countries of our sample. ${ }^{15}$ Quantile regression have many advantages compared to OLS. Indeed, OLS estimators can be inefficient if the errors are non-normal. They are also variant to any monotonic transformations of the data. Specifically, standard linear regression techniques summarize the average relationship between a set of regressors and the outcome variable based on the conditional mean function. This has the drawback of providing a partial view of the relationship as we might be interested to describe the relationship at different points in the conditional distribution of any endogenous variable whose we remove the seasonality. Quantile regression offers the possibility to consider the relationship between the regressors and outcome using conditional median function where the median can be whatever quantile. Moreover, median regression are more robust to outliers than OLS regression. It also allows to consider the impact of a covariate on the entire distribution of the endogenous variable and not merely its conditional mean.

Then, we perform two sets of estimations. We first estimate Taylor rule for the whole sample. We regress the nominal domestic interest rate on the measure of output gap, inflation gap and the lag of the nominal domestic interest rate. For countries that do not belong to Eurozone, we ensure -in order to allow a

\footnotetext{
${ }^{15}$ Due to data avaibility sample ends at 2004Q1 for Croatia, 2010Q4 for Estonia, 2015Q3 for Euro area, 2015Q3 for Greece, 2015Q3 for Ireland, 2013Q4 for Latvia, 2015Q3 for Portugal, 2014Q4 for Romania and 2014Q3 for Spain.
} 
comparison with the standard Taylor rule- that the inclusion of the nominal exchange rate does not lead to Taylor rule that widely differs to Taylor rule without exchange rate. That is why we also estimate Taylor rule including nominal exchange rate.

The main finding of the estimates, exhibited in Figure 14, is that the two Taylor rules are quasi-similar in all CESE countries, albeit to a lesser extent in Croatia. So our approach is robust.

Figure 15 exhibits the respective country-specific Taylor rules with the Eurozone's Taylor rule. Except Poland where we don't identify a particular trend, for all other countries, the adoption of the ECB's monetary policy would accentuate the expansionary bias in the period preceding the Global financial crisis, and then, aggravating the ineffectiveness of monetary policy.

\section{Conclusion}

In this contribution, we investigated the implications of macroeconomic divergences on the conduct of monetary policies in several EU economies. Our different econometric estimates show the ineffectiveness of the one-size-fits all monetary policy approach. Importantly, we stress that such results hold not only for countries of the Eurozone but also for CESE economies.

Three main policy implications are particularly important. First, in line with Brzoza-Brzezina et al. (2013) and Merler (2015), the ineffectiveness of monetary policy to face imbalances -and especially financial imbalances- suggest that the EU should adopt macroprudential measures. Such measures should be calibrated to domestic specificities.

Second, it is critical to improve the effectiveness of fiscal policy. Indeed, the experience of CESE and Peripheral countries suggests that fiscal policy has tended to be pro-cyclical or at least neutral. As a consequence, fiscal policy has been unable to thwart overheating and accumulation of imbalances over time. From this perspective, the fiscal pact should promote counter-cyclical fiscal rules at the ER scale.

Third, to cope with growing imbalances, it seems to us relevant to use the Macroeconomic Imbalance Procedure as a tool to implement automatic adjustment mechanisms. Critically, such mechanisms should be applied for both creditors and debtors countries.

\section{References}

Allegret J.P. and Sallenave A. (2015a), "Capital flow bonanzas and monetary policy in emerging Europe: responses to the global financial crisis", Post-Communist Economies, 27(4): 429-447.

Allegret J.P. and Sallenave A. (2015b), "Capital flows and boom-bust cycle in emerging Europe. Responses to the volatile financial global context", in The European Union and the challenges of the new global context, I. Tache (ed.), Cambridge Scholars Publishing, Newcastle, UK, 208-232. 
Beveridge S. and Nelson C.R. (1981), "A new approach to decomposition of economic time series into permanent and transitory components with particular attention to measurement of the business cycle", Journal of Monetary Economics, 7: 151-174.

Berkmen P., Gelos G., Rennhack R., and Walsh J.P. (2012), "The global financial crisis: explaining cross-country differences in the output impact", Journal of International Money and Finance, 31(1): 42-59.

Blanchard O.J., Griffiths M., and Gruss B. (2013), "Boom, bust, recovery: forensics of the Latvia crisis", Brookings Papers on Economic Activity, Fall: 325-371.

Borio C. (2012), "The financial cycle and macroeconomics: What have we learned?", BIS Working Papers, 395, December.

Box G.E.P., Hillmer, S.C. and Tiao G.C. (1978), "Analysis and modeling of seasonal time series", in Seasonal analysis of economic time series, A. Zellner (ed.). U.S. Department of Commerce, Bureau of the Census, Washington, D.C., 309-334.

Brzoza-Brzezina M., Kolasa M., and Makarski K. (2013), "Macroprudential policy instruments and economic imbalances in the euro area", $E C B$ Working Paper Series, 1589, September.

Buttiglione L., Lane P.R., Reichlin L. and Reinhart V. (2014), "Deleveraging? What Deleveraging?", Geneva Reports on the World Economy, n¹6, International Center for Monetary and Banking Studies, Centre for Economic Policy Research, Geneva and London.

Cesaroni T. and De Santis R. (2015), "Current Account 'Core-Periphery Dualism' in the EMU”, CEPS Working Document, 406, March.

Chen R., Milesi-Ferretti G.M., and Tressel T. (2013), "External imbalances in the Eurozone", Economic Policy, 28(73): 101-142.

Darvas Z. (2015), "The great divergence: Global and European current account surpluses", Bruegel Working Paper, 2015/08, August.

Dellas H. and Tavlas G.S. (2013), "The Gold Standard, the Euro, and the origins of the Greek sovereign debt crisis", Cato Journal, 33(3): 491-520.

Harvey A. (1989), Forecasting, structural time series models and the Kalman filter, Cambridge University Press.

Hodrick R.J. and Prescott E.C. (1980), "Postwar U.S. business cycles: An empirical investigation", Carnegie Mellon University Discussion Paper, 451.

Hodrick R.J. and Prescott E.C. (1997), "Postwar U.S. business cycles: An empirical investigation", Journal of Money, Credit and Banking, 29(1): 1-16.

Hofman B. and Bogdanova B. (2012), "Taylor rules and monetary policy: a global "Great Deviation"', BIS Quarterly Review, September: 37-49.

IMF (2009), "From recession to recovery: How soon and how strong", World Economic Outlook, Chapter 3, 103-138.

Kadowa A., Cerrato M., MacDonald R., and Straetmans S. (2013), "Does the euro dominate Central and Eastern European money markets?", Journal of International Money and Finance, 32: 700-718.

Lothian J.R. (2014), "Monetary policy and the twin crisis", Journal of International Money and Finance, 49: 197-210.

Merler S. (2015), "Squaring the cycle: Financial cycles, capital flows and macroprudential policy in the Euro area", Bruegel Working Paper, 2015/14, November. 
Micossi S. (2015), "The monetary policy of the European Central Bank (20022015)", CEPS Special Report, 109, May.

Mitra P. (2011), "Capital flows to EU New Member states: Does sector destination matter?", IMF Working Paper. WP/11/67. March.

Nechio F. (2011), "Monetary policy when one size does not fit all", FRBSF Economic Letter, Federal Reserve Bank of San Francisco, Issue 2011/18, June.

Pisani-Ferry J. (2013), "The known unknowns and unknown unknowns of European Monetary Union”, Journal of International Money and Finance, 34: 614.

Reis R. (2013), "The Portuguese slump and crash and the Euro crisis", Brookings Papers on Economic Activity, Spring, 143-193.

Suarez J. (2010), "The Spanish crisis: Background and policy challenges", XXIII Moneda y Credito Symposium, December, Mimeo.

Taylor J.B. (1993), Macroeconomic Policy in a World Economy: From Econometric Design to Practical Operation, New York: W. W. Norton \& Company.

Tressel T., Wang S., Kang J.S., and Shambaugh J. (2014), "Adjustment in Euro area deficit countries: Progress, challenges, and policies", IMF Staff Discussion Note, SDN/14/7, July.

Wierzbowska A.(2015), "Transmission of euro area shocks to Central and Eastern European countries. Implications for monetary autonomy problem and business cycles synchronization", Japanese Journal of Monetary and Financial Economics, 3(1): 1-29. 


\section{Appendix}

Data and Sources

\begin{tabular}{lll}
\hline Variables & Definition & Source \\
\hline Nominal interest rates & Short term interest & IMF, International Financial \\
& rate/Money market rates & Statistics \\
Real GDP $(2010=100)$ & & IMF, International Financial \\
& & Statistics \\
Nominal bilateral exchange rate/EUR & & IMF, International Financial \\
& & Statistics \\
Inflation rate change Y/Y & Annual rate of inflation & IMF, International Financial \\
& & Statistics \\
Output gap & Cyclical part of the Hodrick ${ }^{-}$ & Author's \\
& Prescott filter & \\
\hline
\end{tabular}

Figure 1 Annual Government Finance (EDP \& ESA 2010), General Government, Percent of GDP
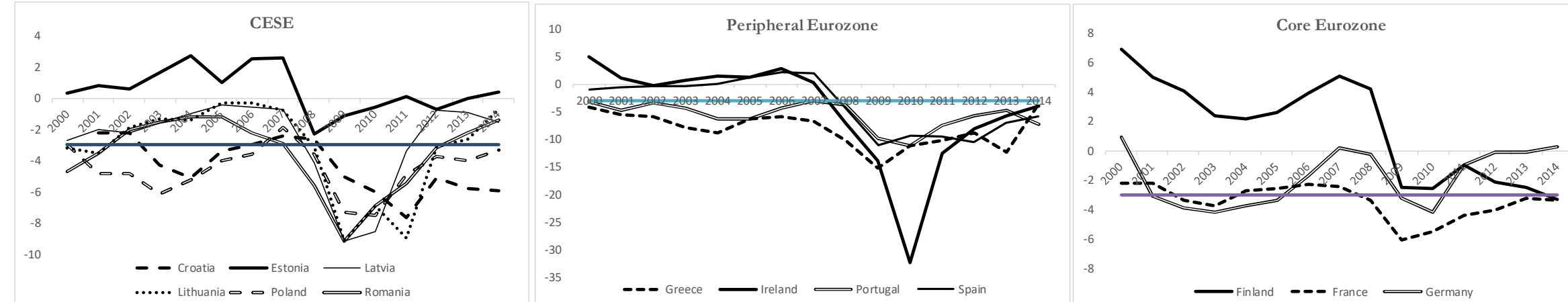

Source: Eurostat, Macroeconomic Imbalance Procedure Scoreboard 
Figure 2 Current Account Balance, Percent of GDP
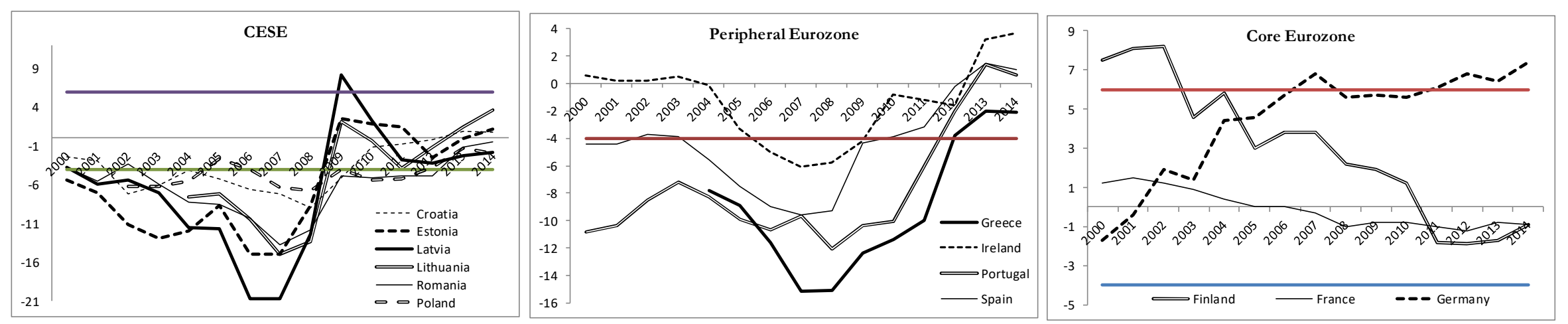

Source: Eurostat, Macroeconomic Imbalance Procedure Scoreboard

Figure 3 Labour Cost, Nominal Unit Labour Cost Index, 3 Year Change
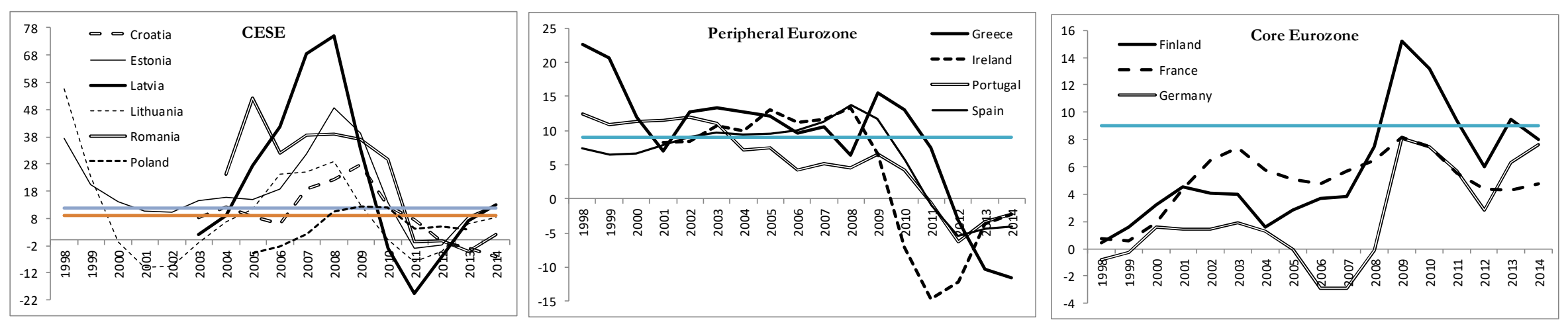

Source: Eurostat, Macroeconomic Imbalance Procedure Scoreboard 
Figure 4 European Commission, Real Effective Exchange Rate Index (Broad Group 42); $2005=100$

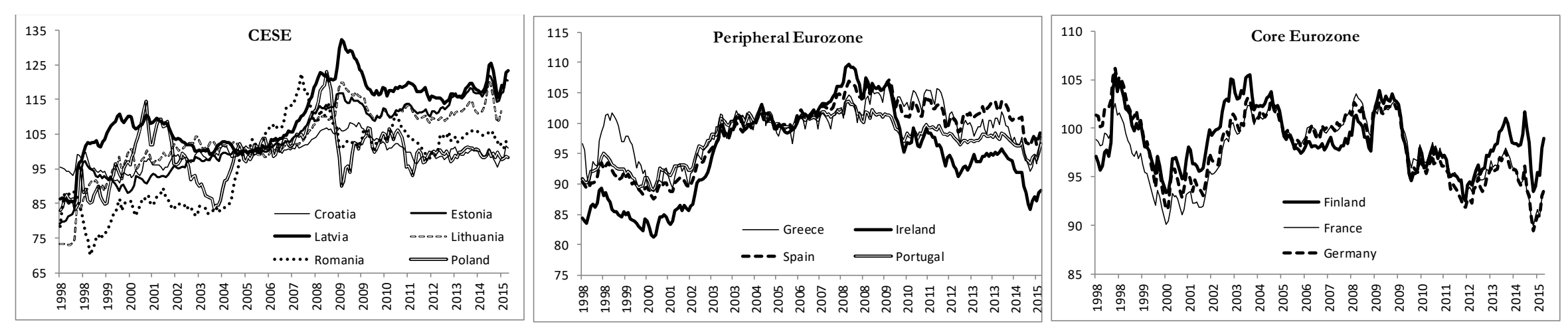

Source: Eurostat, Macroeconomic Imbalance Procedure Scoreboard

Figure 5 Money \& Quasi Money Growth, Change Y/Y
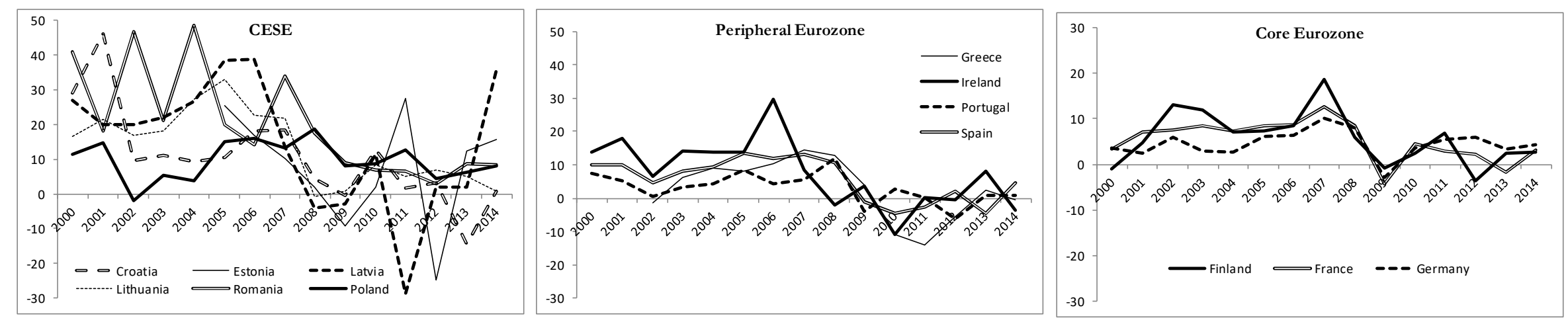

Source: World Bank, World Development Indicators 
Figure 6 Inflation, CPI Percentage Change, Change Y/Y

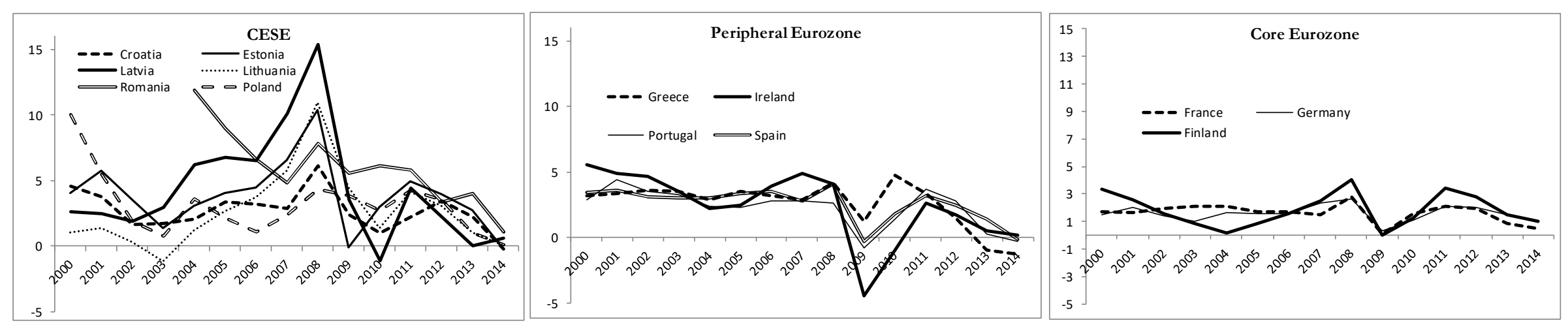

Source: IMF, International Financial Statistics

Figure 7 Long-term interest rates, in real terms
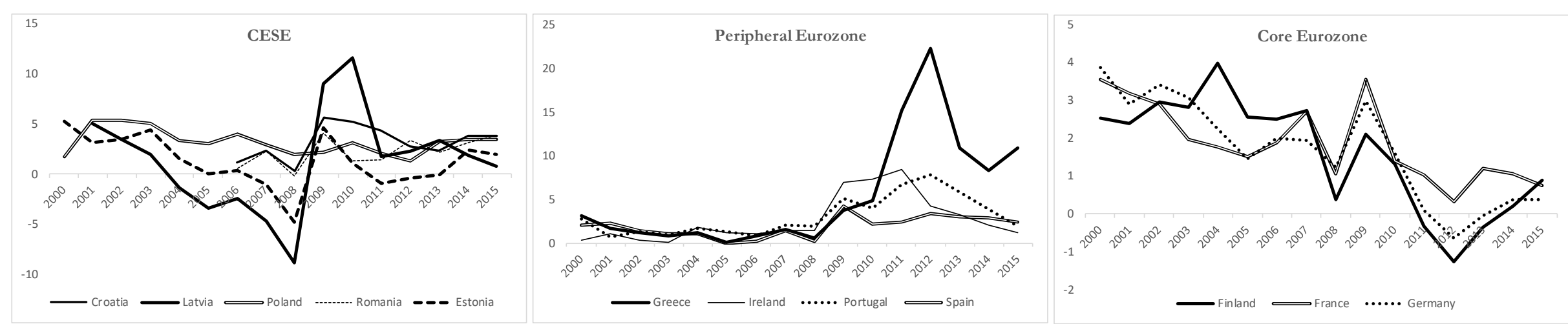

Except Estonia, long-term real interest rates are estimated by using 10 year government bond yield less CPI inflation rate

For Estonia, we use loans to non-financial corporations, long-term, over 10 Years 
Source: authors' estimates. Data extracted from Macrobond

Figure 8 Private sector credit flow in \% of GDP
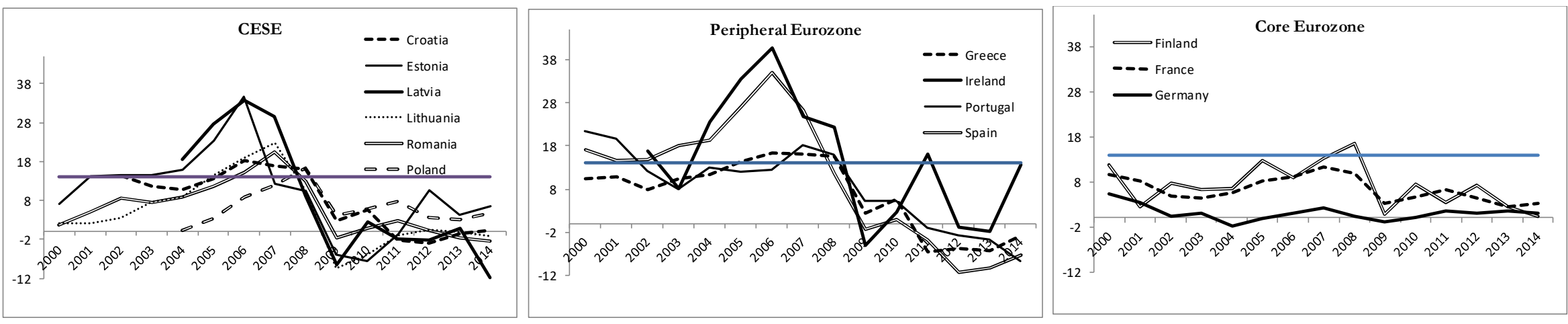

Source: Eurostat, Macroeconomic Imbalance Procedure Scoreboard

Figure 9 Year-on-year changes in house prices relative to consumption deflator
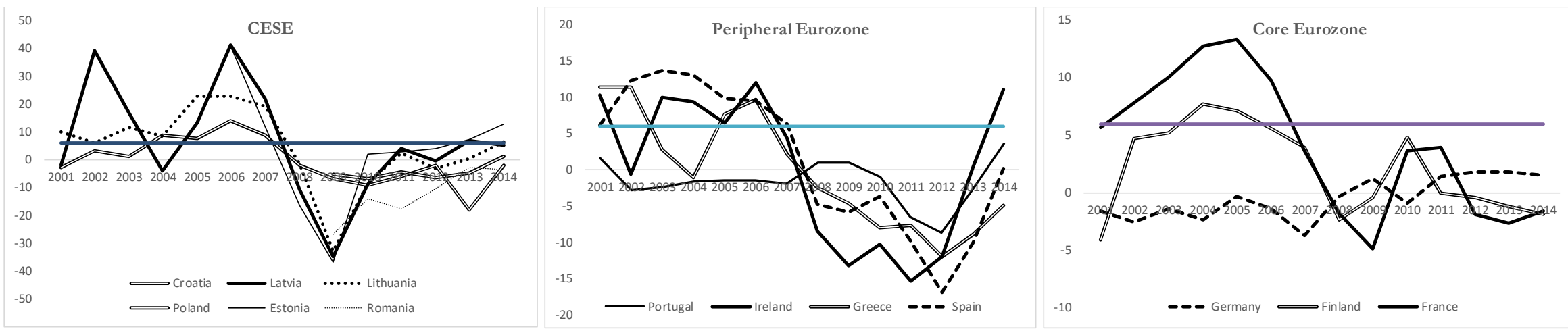

Source: Eurostat, Macroeconomic Imbalance Procedure Scoreboard 
Figure 10 Private Debt, Consolidated, Percent of GDP
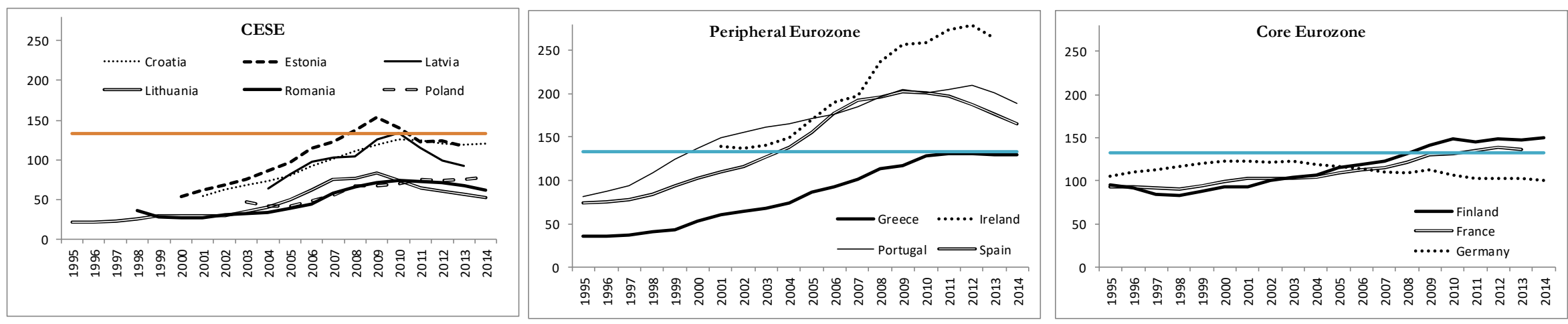

Source: Eurostat, Macroeconomic Imbalance Procedure Scoreboard

Figure 11 Output gap
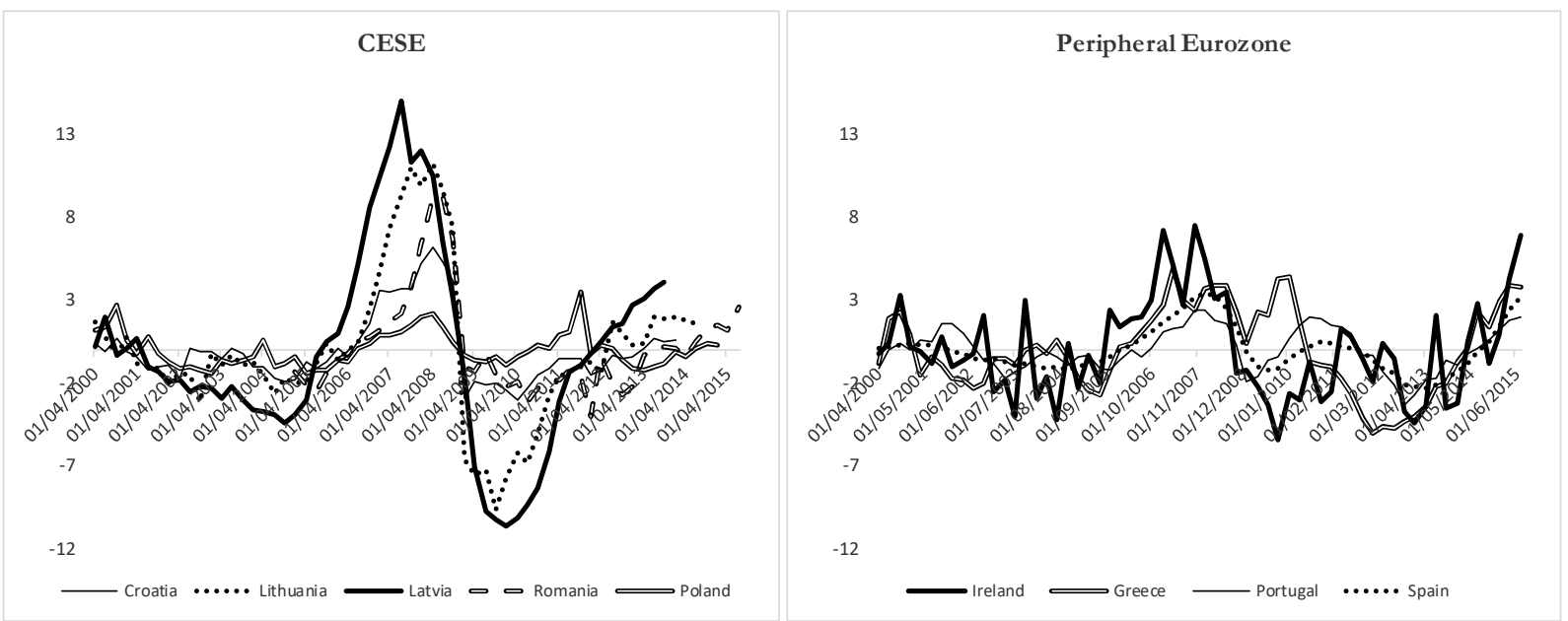

Core Eurozone

13

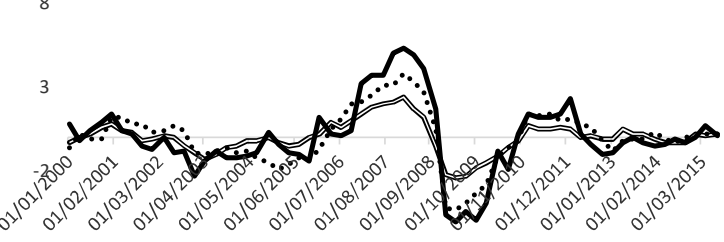

$-12$

Source: Authors' estimates. Data extracted from Macrobond. 

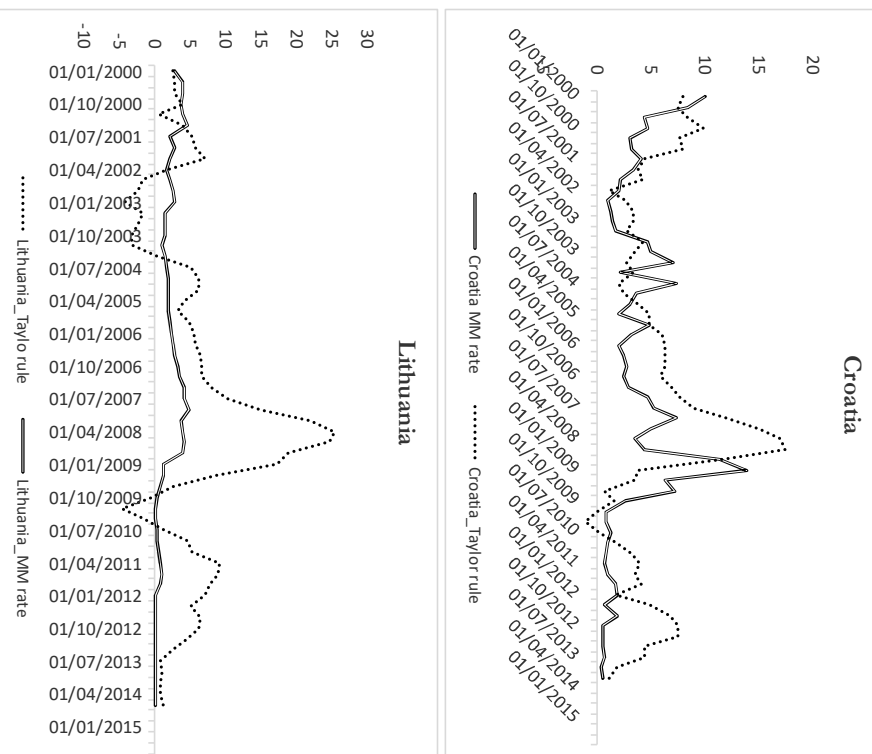

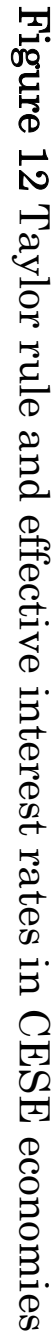

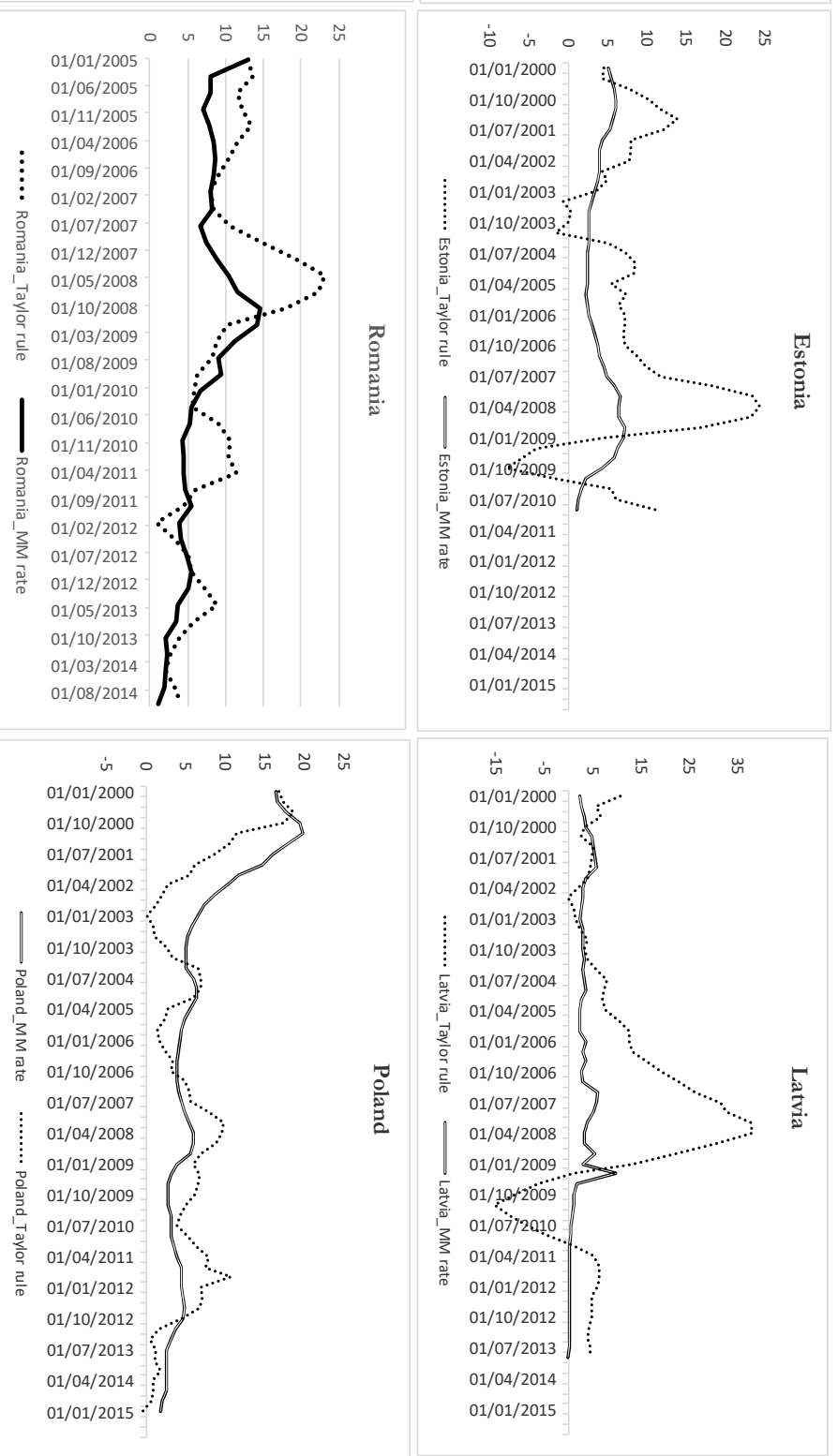


Figure 13 Taylor rule and effective interest rates in Peripheral Eurozone economies

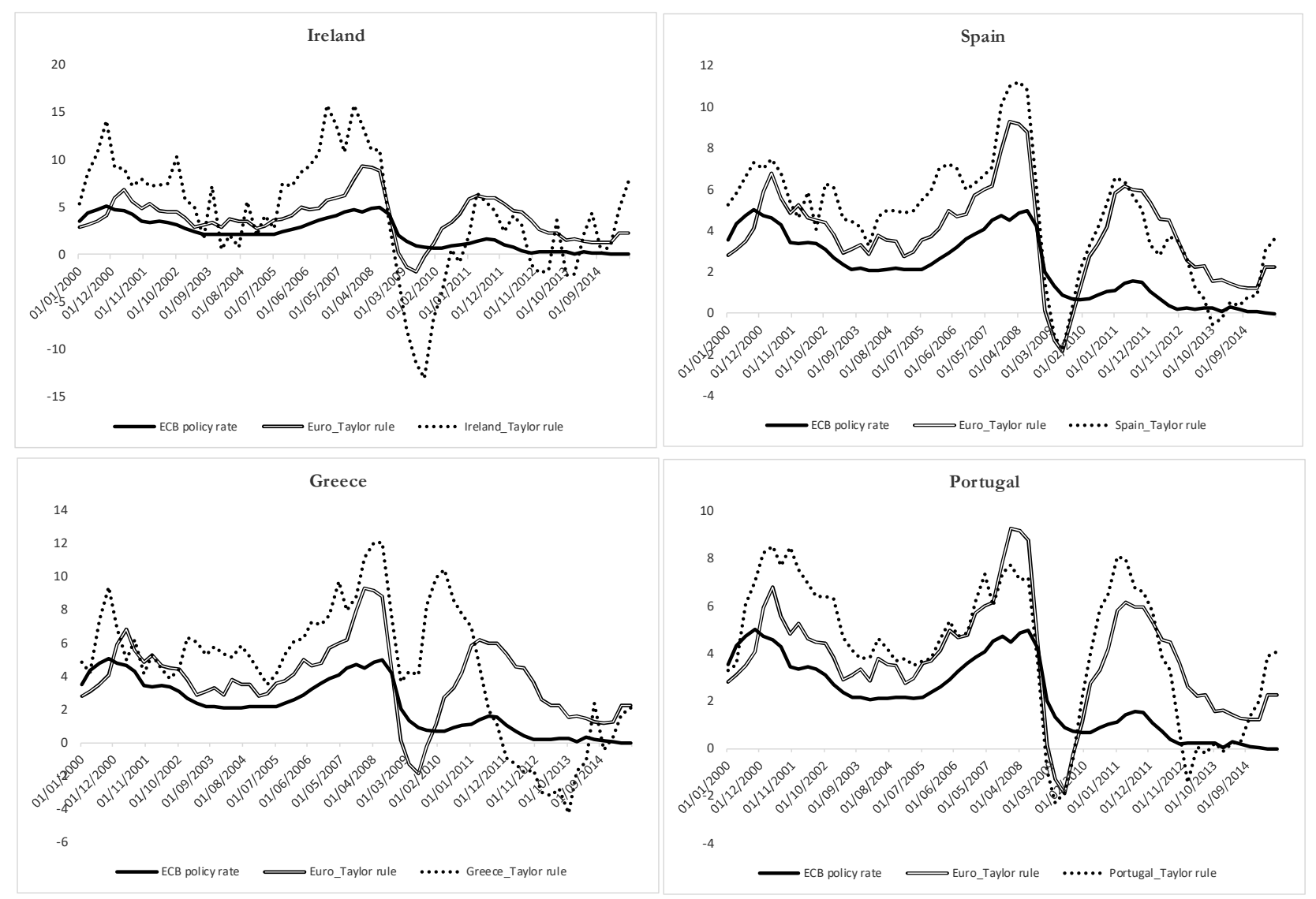

Source: Authors' estimates 


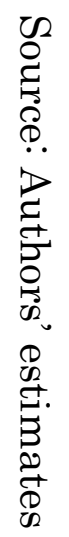
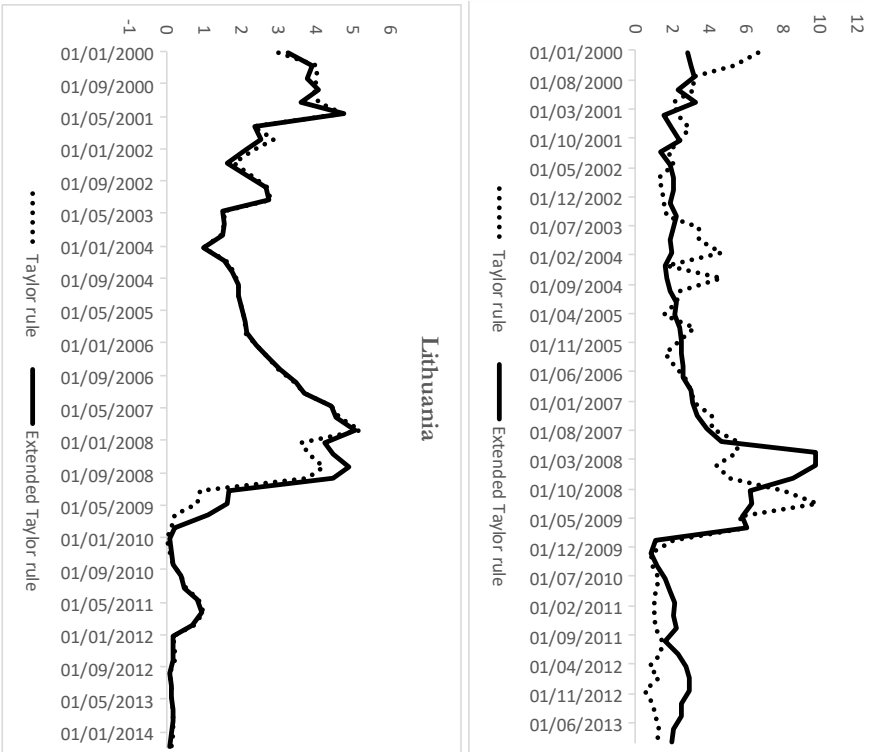

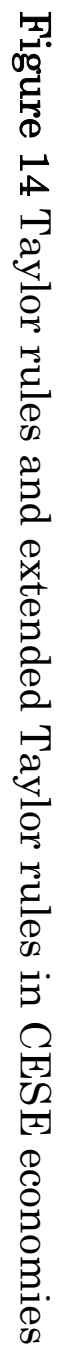
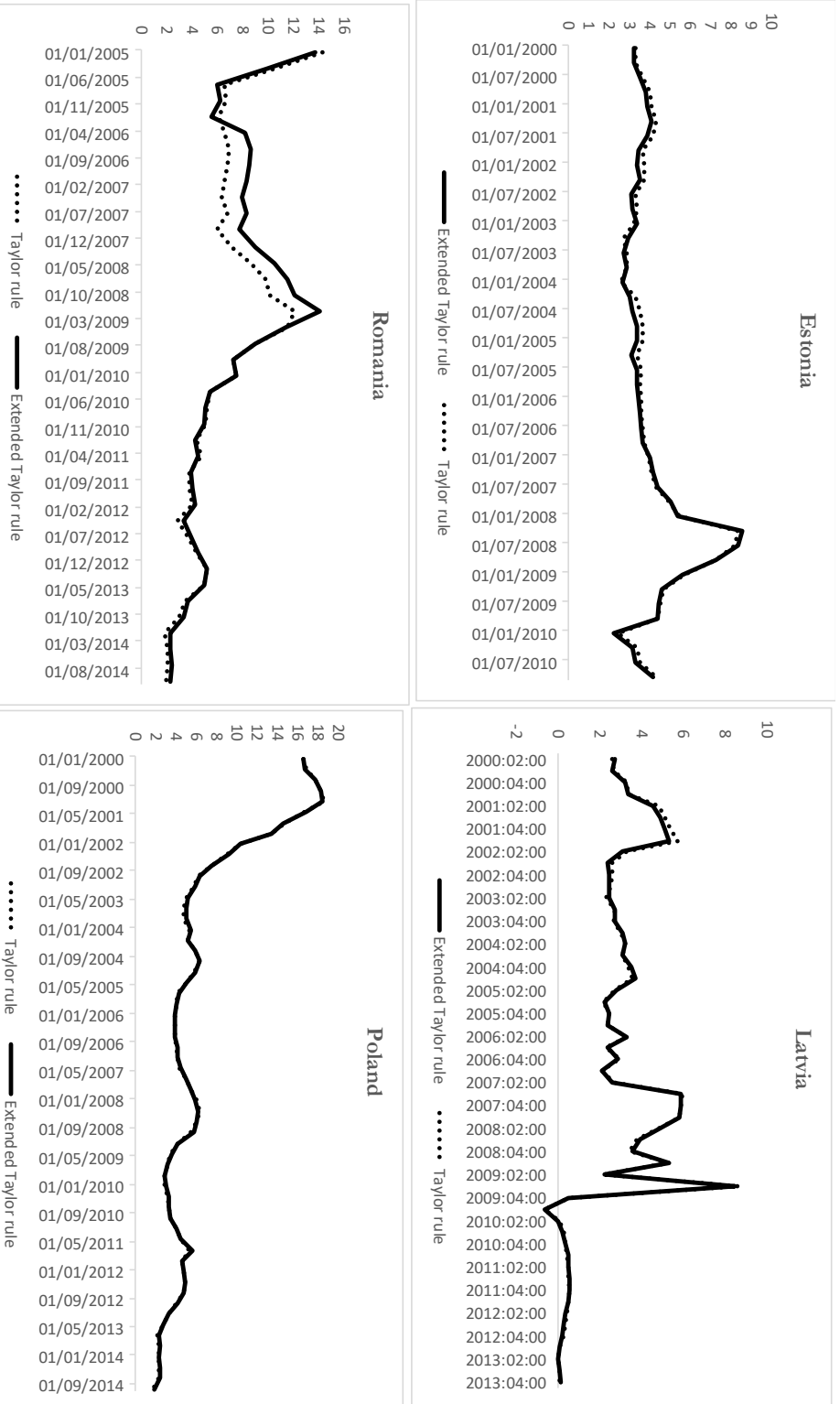


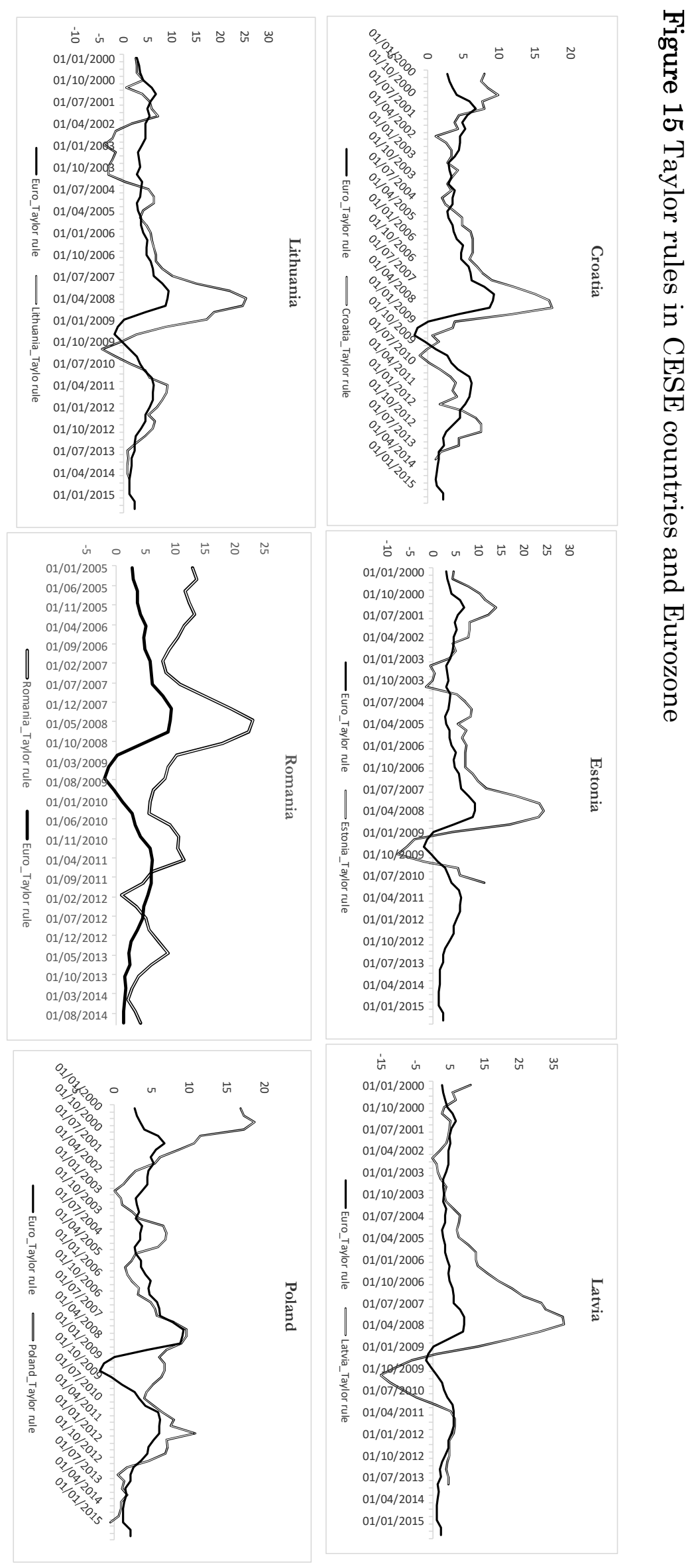

